\title{
Peranan Supervisi dalam meningkatkan Pengembangan Profesionalisme dan Kinerja Guru
}

\author{
Amalini Lutfia Ozila
}

Email : amalinilutfiaozila@gmail.com

\begin{abstract}
Abstrak
Peran Keprofesionalan guru tidak terlepas dari pentingnya sumber daya mansia (SDM). Peran guru mengajar dan mendidik peserta didik dilakukan secara terus-menerus dalam proses pembelajaran untuk meningkatkan segi keterampilan supervisi kependidikan dan kualitas kinerjanya.Penekanan dari Supervisi ini ialah dilandasi persahabatan melalui pelayanan dan kerjasama yang baik antara guru dengan peserta didik.Untuk implementasinya supervisi dilakukan melalui berbagai proses dalam aspek pemecahan masalah yang bertujuan meningkatkan efektivitas dan efisiensi guru.Selain itu juga berfungsi dalam meningkatkan kualitas pembelajaran di Indonesia yang sampai saat ini belum memenuhi standart bahkan jauh dari yang di harapkan. Peran supervisi disini bertanggung jawab dalam peningkatan pembelajaran guru dengan mengikuti perkembangan ilmu pengetahuan dan teknologi dan penggunaan teknik supervisi.
\end{abstract}

\section{Kata Kunci : Profesionalisme, Supervisi dan Kinerja}

\section{LATAR BELAKANG}

Dalam usaha meningkatkan kualitas sumber daya pendidikan, guru adalah komponen sumber daya manusia yang harus dibina dan dikembangkan secara terus-menerus. Pembentukan profesi guru dilaksanakan melalui program pendidikan prajabatan maupun program dalam jabatan. Potensi sumber daya guru itu perlu terus bertumbuh dan berkembang agar dapat melakukan fungsinya secara potensial. Guru merupakan penentu keberhasilan pendidikan melalui kinerjanya pada tataran institusional dan eksperiensial, sehingga upaya meningkatkan mutu pendidikan harus dimulai dari aspek guru.

Di Indonesia sangat sulit untuk terlalu membebaskan guru dalam membelajarkan peserta didik di kelas. Guru tersebut perlu disupervisi oleh kepala sekolah agar dapat meningkatkan profesionalisme dan kinerja mereka dalam membelajarkan peserta didik di kelas. Melalui supervisi tersebut, juga diharapkan kepala sekolah mengendalikan dan menjamin mutu pembelajaran di kelas. Profesionalisme guru dalam proses pendidikan memiliki peran yang sangat strategis dalam membimbing peserta didik ke arah kedewasaan dan kematangan menuju kemandirian.

Guru bukan hanya berperan sebagai pengajar dan menyampaikan materi pelajaran sebagai pertanggungjawaban pembelajaran, melainkan guru harus bertindak sebagai pendidik. Peranan supervisi akademik kepala sekolah dan profesionalisme guru di sekolah sangat besar, karena supervisi yang dilakukan kepala sekolah secara terus menerus dan kontinu dapat meningkatkan mutu pembelajaran yang pada akhirnya dapat meningkatkan mutu pendidikan di Indonesia. Supervisi akademik menjadi dasar atau landasan kegiatan pengawasan profesional, yang menjadi kajian adalah sistem pemberian bantuan yang dilakukan oleh kepala sekolah untuk meningkatkan kemampuan profesional guru, sehingga guru menjadi lebih mampu dalam menangani tugas pokok membelajarkan peserta didiknya.

Sering supervisi dilakukan hanya sampai pada tahap memeriksa rencana pembelajaran atau mengamati pelaksanaan pembelajaran guru di kelas. Seharusnya supervisi dilakukan 
dalam rangka menjamin pembelajaran yang berkualitas. Artinya, bahwa keberhasilan pelaksanaan supervisi diukur dari peningkatan prestasi belajar siswa.

Kurang intensifnya pelaksanaan supervisi akademik disebabkan banyaknya tugas administratif kepala sekolah sehingga sulit meluangkan waktu untuk melakukan supervisi akademik secara intensif. Kondisi demikian jika terus berlanjut akan memberikan efek yang kurang kondusif terhadap peningkatan profesionalisme guru dan mutu pendidikan. Begitu pentingnya peran dan fungsi guru bagi dunia pendidikan, maka kepala sekolah mempunyai peran sentral dalam mengelola personalia khususnya terhadap kompetensi profesional guru di sekolah, sehingga sangat penting kepala sekolah untuk memahami dan menerapkan kompetensi supervisi akademik dengan baik

\section{PEMBAHASAN}

Di abad sekarang ini, yaitu era globalisasi dimana semuanya serba digital, akses informasi sangat cepat dan persaingan hidup semakin ketat, semua bangsa berusaha untuk meningkatkan sumber daya manusia. Termasuk sumber daya pendidikan. Yang termasuk dalam sumber daya pendidikan yaitu ketenagaan, dana dan sarana dan prasarana. Guru merupakan penentu keberhasilan pendidikan melalui kinerjanya pada tataran institusional dan eksperiensial, sehingga upaya meningkatkan mutu pendidikan harus dimulai dari aspek guru dan tenaga kependidikan lainnya yang menyangkut kualitas keprofesionalannya maupun kesejahteraan dalam satu manajemen pendidikan yang professional. Profesionalisme menjadi tuntutan dari setiap pekerjaan. Apalagi profesi guru yang sehari-hari menangani peserta didik dengan berbagai karakteristik yang masing-masing tidak sama.

Guru yang profesional amat berarti bagi pembentukan sekolah unggulan. Guru profesional memiliki pengalaman mengajar, kapasitas intelektual, moral, keimanan, ketaqwaan, disiplin, tanggungjawab, wawasan kependidikan yang luas, kemampuan manajerial, trampil, kreatif, memiliki keterbukaan profesional dalam memahami potensi, karakteristik dan masalah perkem-bangan peserta didik, mampu mengembangkan rencana studi dan karir peserta didik serta memiliki kemampuan meneliti dan mengembangkan kurikulum.

Pendekatan yang dapat dilakukan oleh seorang supervisor terhadap guru dalam rangka melaksanakan, mengoreksi, memperbaiki dan membina proses belajar mengajar bersama guru, diantaranya adalah ,Pendekatan professional dalam supervisi adalah pendekatan professional. Kata professional menunjukkan pada fungsi utama guru yang melaksanakan pengajaran secara professional. Mengajar sebagai profesi menjadikan tugas guru secara langsung menyentuh manusia menyangkut kepentingan dan kebutuhannya untuk tumbuh dan berkembang kearah kedewasaan dan kemandirian melalui proses pembelajaran, maka sasaran supervisi juga harus mengarahkan pada hal-hal yang menyangkut tugas mengajar itu, dan bukan tugas guru yang sifatnya administratif. Dalam lingkup sekolah maka yang dapat dikatakan sebagai supervisor yaitu kepala sekolah. Karena kepala sekolah sebagai administrator terdepan dan jelas berkaitan dengan guru khususnya dalam kegiatan proses pembelajaran. Selain itu wakil kepala sekolah, maupun kepala sumber belajar juga bisa membimbing guru-guru lain untuk membantu peningkatan kompetensi profesionalnya.

Prespektif Supervisi Pendidikan

Supervisi pendidikan berkembang seiring berkembangkan ilmu manajemen.Pendekatan supervisi bergerak ke arah yang lebih demokratis; supervisor dan guru dapat saling bertukar pendapat tentang peningkatan kualitas pembelajaran. Perkembangan supervisi dewasa ini lebih menekankan kepada upaya guru untuk mengembangkan kualitas pembelajarannya melalui pengembangan keprofesionalan berkelanjutan. Sehubungan perkembangan 
pengetahuan dan teknologi yang berkembangan pesat dalam waktu yang sangat singkat, supervisor dengan jumlah

Perkembangan supervisi pendidikan berkembang seiring dengan perkembangan ilmu pengetahuan, teknologi, serta sosial ekonomi dan budaya masyarakat. Supervisi bergerak dari berbentuk inspeksi dimana otoritas lebih didominasi oleh supervisor, berkembang dalam bentuk kolaborasi antara supervisor dan guru bersama berinisiatif dan bertanggungjawab dalam meningkatkan kualitas pembelajaran, serta menumbuhkan budaya belajar pada guru untuk selalu meningkatkan kompetensinya.

Pendekatan Supervisi

a. Supervisi Klinis

Kata "klinis" menunjuk pada muka antara guru dan supervisor pada pemecahan masalah reflektif, target secara langsung masing-masing kelas, dan terfokus pada guru sebagai agen perubahan. Memiliki kapasitas mengembangkan kemampuan guru untuk bertanggung jawab menganalisis kinerja mereka, terbuka membantu orang lain, danmengarahkan diri sendiri. dilakukan dalam bentuk proses tatap muka yang memungkinkan supervisor dan guru bersama membahas dan menganalisis masalah pembelajaran yang terjadi di kelas dan menemukan mengatasi masalah tersebut.

b. Supervisi Pengembangan

Didasarkan pada asumsi bahwa guru memiliki beragam pengalaman, kemampuan, dan tingkat pengembangan karir yang berbeda. Oleh sebab itu, supervisor menentukan kebutuhan supervisi guru berdasarkan perbedaan individual, keahlian, dan komitmen. Karenanya dapat menggunakan pendekatan supervisi untuk guru yang berbeda. Dengan kata lain, supervisi pengembangan memberikan guru banyak pilihan sebagaimana keadaan guru dan mempercepat pengambilan keputusan dan menyesuaikannya setiap waktu yang diperlukan.

Peran seorang supervisor yaitu membantu (Assisting), dorongan (Supporting), dan mengikutsertakan (Sharing). Berkaitan dengan peran sebagai supervisor maka peran kepala sekolah yaitu membantu guru dalam memahami tujuan pendidikan, membantu guru dalam menggunakan sumber-sumber, metode dan alat pelajaran, membantu guru dalam memenuhi kebutuhan dan membimbing pengalaman belajar siswa, membantu guru menilai kemajuan-kemajuan dan hasil pekerjaan siswa, membantu guru untuk lebih bisa bersosialisasi dengan masyarakat, serta membantu reaksi mental dan moral kerja guru dalam rangka pertumbuhan pribadi dan jabatan mereka.

Kepala sekolah mempunyai beberapa peran penting yaitu sebagai berikut :

1. Peran pembimbingan yaitu membimbing guru agar dapat memahami secara lebih jelas masalah atau persoalan-persoalan dan kebutuhan murid serta membantu guru dalam mengatasi persoalan, memberikan bimbingan yang bijaksana terhadap guru baru dengan sifat materinya.

2. Peran memberi bantuan yaitu membantu guru dalam mengatasi kesukaran dalam mengajar, membantu guru memperoleh kecakapan mengajar yang sesuai dengan sifat materinya, membantu guru memperkaya pengalaman belajar sehingga suasana pengajaran bisa menggembirakan anak didik, dan membantu guru mengerti makna dari alat-alat pelajaran.

3. Peran memberikan layanan yaitu memberi pelayanan kepada guru agar dapat menggunakan seluruh kemampuannya dalam melaksanakan tugas.

4. Peran pembinaan yaitu membina moral kelompok, menumbuhkan moral yang tinggi dalam pelaksanaan tugas.

Pendapat tersebut menunjukkan adanya aktifitas supervisi antara kepala sekolah dan guru yang meliputi kegiatan pembimbingan, bantuan, layanan, serta pembinaan yang berkaitan dengan peningkatan kemampuan guru dalam proses pembelajaran. 
Kegiatan supervisi bermaksud untuk menjaga dan memelihara kualitas seorang guru, dalam proses pembelajaran di sekolah, kegiatan supervise sangat penting bila menginginkan kualitas pendidikan yang baik di sekolah, hal ini disebabkan karena supervisi merupakan bantuan terhadap guru. Peranan supervisi akademik kepala sekolah dan profesionalisme guru di sekolah sangat besar, karena supervisi yang dilakukan kepala sekolah secara terus menerus dan kontinu dapat meningkatkan mutu pembelajaran yang pada akhirnya dapat meningkatkan mutu pendidikan di Indonesia. Supervisi akademik menjadi dasar atau landasan kegiatan pengawasan profesional, yang menjadi kajian adalah sistem pemberian bantuan yang dilakukan oleh kepala sekolah untuk meningkatkan kemampuan profesional guru.

Keberhasilan seorang guru dalam kegiatan-kegiatan pengajaran sebagian besar bergantung pada tingkat orientasi dan penguasaan yang dimilikinya atas bidangbidang materi subjek yang diajarkannya. Guru dituntut memiliki kinerja yang mampu memberikan dan merealisasikan harapan dan keinginan semua pihak terutama masyarakat umum yang telah mempercayai sekolah dan guru dalam membina anak didik. Dalam meraih mutu pendidikan yang baik sangat dipengaruhi oleh kinerja guru dalam melaksanakan tugasnya sehingga kinerja guru menjadi tuntutan penting untuk mencapai keberhasilan pendidikan. Secara umum mutu pendidikan yang baik menjadi tolok ukur bagi keberhasilan kinerja yang ditunjukkan guru.

Guru sebagai pekerja harus berkemampuan yang meliputi penguasaan materi pelajaran, penguasaan profesional keguruan dan pendidikan, penguasaan cara-cara menyesuaikan diri dan berkepribadian untuk melaksanakan tugasnya, disamping itu guru harus merupakan pribadi yang berkembang dan bersifat dinamis. Hal ini sesuai dengan yang tertuang dalam Undang-undang No. 20 tahun 2003 tentang Sistem Pendidikan Nasional bahwa pendidik dan tenaga kependidikan berkewajiban :

- menciptakan suasana pendidikan yang bermakna, menyenangkan, kreatif, dinamis, dan dialogis,

- mempunyai komitmen secara profesional untuk meningkatkan mutu pendidikan

- memberi teladan dan menjaga nama baik lembaga, profesi, dan kedudukan sesuai dengan kepercayaan yang diberikan kepadanya.

Harapan dalam Undang-Undang tersebut menunjukkan adanya perubahan paradigma pola mengajar guru yang pada mulanya sebagai sumber informasi bagi siswa dan selalu mendominasi kegiatan dalam kelas berubah menuju paradigma yang memposisikan guru sebagai fasilitator dalam proses pembelajaran dan selalu terjadi interaksi antara guru dengan siswa maupun siswa dengan siswa dalam kelas. Kenyataan ini mengharuskan guru untuk selalu meningkatkan kemampuannya terutama memberikan keteladanan, membangun kemauan, dan mengembangkan kreativitas peserta didik dalam proses pembelajaran.

Seorang supervisor hendaknya membangkitkan dan memelihara kegairahan kerja guru untuk mencapai prestasi kerja yang semakin baik. Guru-guru didorong untuk mempraktikkan gagasan-gagasan baru yang dianggap baik bagi penyempurnaan proses pembelajaran, bekerjasama dengan guru (individu atau kelompok) untuk mewujudkan perubahan yang dikehendaki, merangsang lahirnya ide baru, dan menyediakan rangsangan yang memungkinkan usaha-usaha pembaruan dapat dilaksanakan dengan sebaik-baiknya.

\section{KESIMPULAN}


Kebijakan pendidikan harus ditopang oleh pelaku pendidikan yang berada di front terdepan yakni guru melalui interaksinya dalam pendidikan. Upaya meningkatkan mutu pendidikan perlu dilakukan secara bertahap dengan mengacu pada rencana strategis. Keterlibatan seluruh komponen pendidikan dalam perencanaan dan realisasi program pendidikan yang diluncurkan sangat dibutuhkan dalam rangka mengefektifkan pencapaian tujuan. Implementasi kemampuan profesional guru mutlak diperlukan sejalan diberlakukannya otonomi daerah, khsususnya bidang pendidikan. Kemampuan profesional guru akan terwujud apabila guru memiliki kesadaran dan komitmen yang tinggi dalam mengelola interaksi belajar-mengajar. Salah satu upaya peningkatan profesional guru adalah melalui supervisi pengajaran. Pelaksanaan supervisi pengajaran perlu dilakukan secara sistematis oleh kepala sekolah dan pengawas sekolah bertujuan memberikan pem-binaan kepada guru-guru agar dapat melaksanakan tugasnya secara efektif dan efisien

\section{SARAN}

Berdasarkan uraian dan kesimpulan diatas, maka disarankan kepada kepala sekolah dalam kegiatan penilaian kinerja guru diharapkan dilaksanakan dengan sebenarbenarnya sesuaikondisi nyata di lingkup kerjanya. Bagi Guru seyogyanya lebih mamahami atasannya maupun rekan kerjanya baik secara personal maupun secara professional. Secara personal maksudnya, guru membangun hubungan yang baik antar individu dengan kepala sekolah maupun rekan kerjanya sebagaimana kompetensi sosial seorang guru. secara profesional maksudnya guru diharapkan dapat memiliki hubungan atasan dengan bawahan maupun sesame guru secara profesional sebagaimana ketentuan yang berlaku

\section{REFERENSI}

Administrasita, J. I. (1967). Jurnal Ilmiah Administrasita' (ISSN 2301-758) 266.

Maralih. (2014). Peranan Supervisi Dalam Peningkatan Kualitas Pendidikan. 1(1), 179-192.

Pendidikan, J., Sekolah, G., \& Edisi, D. (2016). supervisi pendidikan, kinerja guru. (3),114 120.

Suwartini, E. A. (2017). Supervisi Akademik Kepala Sekolah, Profesionalisme Guru dan Mutu Pendidikan. Jurnal Administrasi Pendidikan, Vol. XXIV,(No. 2), hal. 62-70.

Supandi. 1986. Administrasi dan Supervisi Pendidikan. Jakarta: Departemen Agama Universitas Terbuka.

Suryasubrata.1997. Proses Belajar Mengajar di Sekolah. Jakarta: Rineka Cipta.

Sabandi, A. (2013). Supervisi Pendidikan Untuk Pengembangan Profesionalitas Guru Berkelanjutan. Jurnal Ilmiah Ilmu Pendidikan, XIII(2), 1-9. 